\title{
Some Issues of Vocabulary Teaching of Bulgarian as a Foreign Language
}

\author{
Radostina Stoyanova \\ Department of Foreign Languages \\ College of tourism, University of Economics - Varna \\ Varna, Bulgaria \\ e-mail: radostina_stoyanova@mail.ru
}

\begin{abstract}
The universally accepted strategy for working with vocabulary in foreign language teaching presupposes two stages: the definition of the lexical items and their automatization. The current problem facing language teaching lies in how to compiling lexical minimum of Bulgarian as a foreign language for people's different levels of competence in Bulgarian learning. According to the Common European Framework of Reference for Languages. The levels are Learning, Teaching, AssessmentCEFR.
\end{abstract}

Keywords-Bulgarian as foreign language; teaching vocabulary; lexical minimum; definition; automatization

\section{INTRODUCTION}

The main purpose of vocabulary teaching in Bulgarian as foreign language course is to develop students' vocabulary skills, i.e. the automatic choice of a specific lexical item which corresponds to the original idea and which agrees with the collocation rules for matching other items in speech production, as well as their automatic reception and semantic association in speech perception.

A lexical item is considered to be acquired in case that the learner has mastered its semantics, its phonetic and graphical form and its lexical and grammatical collocation with other lexemes in speech in a given intercultural situation.

An intercultural situation assembles representatives of different cultures and as a result of that, it is possible for each of them to interpret the given situation differently. Therefore, it is necessary for each of the participants to make sure that his interpretation of the situation agrees with that of other participants. Therefore, the process of teaching a foreign language (and of Bulgarian in particular) demands a special emphasis on the relation between the words of the native language and the second language, taking cultural differences in the content of the vocabulary that is being learned into consideration.

\section{Problems Facing Vocabulary Teaching}

The most common approach to introducing a group of new vocabulary is to translate it into the learner's native language or some intermediary language, sometimes accompanied by cultural commentaries, which might seem adequate for the purpose of communication. However, actually, this often does not prevent difficulties from popping up in mutual comprehension. Hence the failures in communication with native speakers of the language. Thus, it is of the same importance, even at the stage where the new vocabulary is firstly introduced, to explain differences in the cultural significance of the vocabulary, which manifest themselves in different associations evoked as soon as a given word is uttered.

As far as such cultural associations are concerned, lexical items manifest themselves as concepts reflecting certain cultural connections and relations. Thanks to the social experience in a given cultural environment these connections come into being as one's memory so as to influence his/her evaluation of reality. In this way these associations reflect the historical development of a given society and convey cult-urology information.

As a result, the process of foreign language teaching, and in particular the teaching of Bulgarian as a foreign language, demands that even at the stage where a group of new vocabulary is introduced, the learners should be instructed what concepts and associations a given word evokes in the consciousness of the native speakers. In this case, the explanation of differences that emerge when interpreting the concepts may as well be carried out in the learners' native language depending on his level of competence.

\section{Sequence ANd Methods of Vocabulary Teaching}

The learners' mastering of a Bulgarian lexical item marked with its cultural associations facilitates intercultural communication and fosters a correct understanding of texts that reflect Bulgarian culture (speeches, songs, films, TV shows etc.).

Psychologists and experts in the methodology of foreign language teaching emphasize another important aspect of learning foreign vocabulary, namely, the minimum basic vocabulary should be acquired at the same time as the structure of the sentence because it can promote a more rapid mastery of the foreign vocabulary. Thus, effective acquisition of foreign vocabulary must be carried out not via the learning of individual lexical items, but by building up of a definite sequence, that is "word - sentence - connected speech".

\section{A. Acquisition of the culturally-marked words}

Learning new vocabulary that contains a cultural 
component begins with comprehension, both auditory and visual. To facilitate learners, you can give them tasks to find a culturally-marked word in the context; to analyze the reaction of a classmate with a different culture; to come up with hypotheses regarding the differences in cultural perceptions reflected in the semantics of the lexical items that became an obstacle in having normal communication in the process of intercultural exchange.

\section{B. Definition of the lexical items}

The next stage after the acquisition of the culturally-marked word is definition. The correct definition of the lexical item, where it is firstly introduced, is of great importance for its correct acquisition and stay in one's memory. The very nature of the lexical items containing a cultural component excludes the use of translation in their definition. In this case, definition can be carried out by including the word in a certain context that is closely related to a certain real situation.

a) The definition of vocabulary that has no equivalent uses a systematic cult-urology commentary. Basic methods of defining the vocabulary of this kind are: giving a definition of the concept by using words that are already familiar to the learners; describing with synonyms, antonyms and homonyms; using visual aids; showing the functioning of the word in a context; using derivational analysis; putting the word in a series of words, showing generic-specific relations.

For example, the definition of the words used for specific phenomena from the Bulgarian lifestyle, culture and traditions such as 'кавал' / 'kaval', 'гъдулка' / 'gadulka' and 'мартеница' / 'martenitsa' demands the use of visual aids, which are either the actual objects or their pictures.

b) The definition of lexical items from the social, political and historical vocabulary demands an explanation of the meaning by introducing a definition of the concept. For example, the word 'хъшове' / 'hashove' can be explained as 'български революционни емигранти във Влахия, които жевеели в бедност и търсели начин да помогнат на освобождението' / 'Bulgarian revolutionaries, who emigrated to Wallachia, where they lived in poverty, seeking various ways of helping the liberation movement'.

c) Definition by putting the word in a series of words which can show generic-specific relations can be used with the explanation of the word. For example, 'сезон' - 'пролет, лято, есен, зима' / 'season' - 'spring, summer, autumn, winter'.

d) The use of synonyms in definition is an extremely important means of revealing the lexical meaning of the new word. Synonymy enriches and expands the learner's lexical competence. When teaching Bulgarian as a foreign language at the beginner's level, the use of synonyms is somewhat relative because words are presented as identical in meaning with their equivalents. The use of synonym series is common at a more advanced level of teaching, for example, 'красив (beautiful) - хубав (pretty), напет (dashing), гиздав (natty), красен (beautiful), прелестен (delightful), очарователен (fascinating), ненагледен (stunning), изящен (exquisite), строен (shapely), прекрасен (lovely), грациозен (graceful), разкрасен (beautified)' and so on.

e) Another means for achieving a more correct definition of new lexical items is the use of antonyms ('светло' - 'тьмно' / 'light' - 'dark'), which can be done at any level of teaching Bulgarian as a foreign language.

f) The definition of some commonly encountered words even at the beginner's level of teaching demands the use of homonyms tоо ('стол- предмет, мебел за сядане' / 'stool' an object, furniture item to sit on, and 'стол - място за общественно хранене' / 'stool' - a food service establishment).

g) The use of the contextual way of definition is common with words and phrases that have a figurative meaning too: Черно море е морската врата на България към света (The Black sea is the marine gateway of Bulgaria to the world). This example shows that the functioning of a word in a context can facilitate the mastery of the richness of the Bulgarian language.

h) The use of derivational analysis is another means of facilitating the definition of lexical units in Bulgarian and it leads to expansion of the learner's vocabulary. It uses semantic-stylistic commentary. For example, since Bulgarian people' are awareness of the culturally-marked names Иванчо / Ivancho and Марийка / Mariyka (personages from popular and not particularly decent anecdotes), we should give the explanation that they are colloquial and emotionally marked diminutive names of Ivan and Maria.

When introducing kinship terms in Bulgarian language which exist neither in the learner's native language nor in the intermediary language, it is necessary to combine different means of definition: giving an interpretation or a definition with a lexical-stylistic analysis that reveals the typical context in which the word is used in Bulgarian speech culture. For example: 'стринка - леля, тетка, вуйна' (aunt), 'стринка съпруга на чичото (брата на бащата)' / 'aunt- wife of one's father's brother'.

i) Grouping words in derivational series facilitates the definition. Therefore it should be used even at the beginner's level of teaching Bulgarian as a foreign language. For example, when the words 'купувам' (buy) and 'продавам' (sell) are introduced, it is useful to introduce the words 'купувач/купувачка' (buyer masc./fem.) and 'продавач/продавачка' (seller masc./fem.). At a more advanced level we can offer larger derivational series of words with familiar, as well as new words.

j) Definition through translation is commonly encountered in cases when the teacher has mastered the learner's native language or the intermediary language. This means of introducing new vocabulary is mostly used when meeting abstract words. However, it is important that the related words from the two languages have an equal range of meaning.

Vocabulary acquisition in Bulgarian teaching as a foreign language also demands that we take into consideration the characteristics of the word with regard to the grammatical 
system. The connection with the grammar should be pointed out when introducing each new word.

The acquisition of a new lexical item has to be done in relation to its functioning in the intercultural context.

\section{Automatization}

Vocabulary definition is the preliminary stage, followed by automatization, in the process of which the function of the word is acquired, i.e. the situational collocation of the word. Lexical items should be introduced from the very start "in a situation", not "first out of a situation, and then in a situation". The lexical habit is related to the situation in the process of talking.

The lexical habit is a synthesized activity of the choice of a lexical item and its correct combination with other lexemes that agrees with the original idea of speech.

The lexical intercultural speech habits are formed on the basis of training the acquired vocabulary. That is achieved by the repeated conscious performance of definite activities in learning communicative situations. Thanks to them, vocabulary is memorized and used in the learner's real-life personal experience.

Training vocabulary with the aim to acquire words can be done by doing various exercises, which ensures the understanding of meanings of new lexical items and phrases. Lexical exercises fall into two groups, i. e. exercises aiming at memorizing the lexical items, its semantics together with its pronunciation and its grammar structure; exercises aiming at building up habits of using the lexical item in the intercultural dialogue.

\section{BASIC CRITERIA FOR COMPILING THE MINIMAL LEXICAL LISTS OF BULGARIAN AT DIFFERENT LEVELS}

Another current problem that still waits to be solved even though it has been raised more than once in the discussion of methodology in teaching Bulgarian as a foreign language, is how to compile the minimal lexical lists of Bulgarian for learners with different levels of competence in Bulgarian. According to the Common European Framework of Reference for Languages:there are three levels, namely, Learning, Teaching, Assessment - CEFR.

The selection of lexical items for the minimal lexical list for each level can most effectively be carried out according to the following criteria:

- stylistic neutrality,

- large derivational potential,

- occurrence in a large number of different collocations,

- semantic value, i.e. ability to denote frequently encountered objects and phenomena,

- frequency of occurrence in public speaking and in writing,

- frequency of occurrence in textbooks and handbooks of Bulgarian as a foreign language.
This set of basic criteria can be expanded by adding two more: the ability of the lexical item to appear as part of different phraseological collocations and its situational-thematic correspondence.

The minimal lexical lists for Bulgarian as a foreign language at each competence level (A1, A2, B1, B2, C1) should be viewed as a special kind of complex multifunctional learner's dictionary which contains lexical items that have been selected, described and structured in a specific way. In this case, it is both necessary and sufficient for the successful realization of communicative tasks in the given intercultural situation.

\section{CONCLUSION}

To sum up, teaching vocabulary in a Bulgarian as a foreign language course, at different levels of teaching, should aim not only at mastering the semantics of lexical items, but also at building up the learner's individual perceptions about the Bulgarian people, about Bulgarian culture and about Bulgaria as a European country.

\section{REFERENCES}

[1] Berdichevsky A.L., Giniatullin I.A., Lyssakov I.P., Passov E.I. Methodology of intercultural education by means of Russian as a foreign language. The book for a teacher / edited by A.L. Berdichevsky. Moscow: the Russian language. Courses,2011.

[2] Passov E.I. Principles of communication theory and technology of foreign language education: methodological manual for teachers of Russian as a foreign language / E. I. Passov, N.E. Kuzovlev. Moscow: the Russian language. Courses, 2010.

[3] Petrova S. Българският език като чужд (history and methodology). Sofia, 1997. 